\title{
Direction of Trade and Changing Export Pattern of Chilli
}

\author{
P. A. Gade ${ }^{1}$, S. S. More ${ }^{2}$ and R. D. Shelke ${ }^{1 *}$ and A. R. Nalegaonkar ${ }^{1}$ \\ ${ }^{1}$ Department of Agricultural Economics, College of Agricultural, Latur, India \\ ${ }^{2}$ Department of Agricultural Economics, College of Agricultural, Parbhani, India \\ *Corresponding author
}

\section{A B S T R A C T}

Chilli (Capsicum annuum L.) is an important vegetable cum spice crop valued for its aroma, taste, flavor and pungency grown in all parts of world. It belongs to the family solanaceae with the chromosome number $2 n=24$ and centre of origin of hot chilli is Mexico. chilli is one of the most valuable spice crop than other spices. It is used in India as

\section{Keywords}

Chilli, Direction of trade, Markov chain analysis,

Transitional probability

\section{Article Info}

Accepted: xx October 2020 Available Online: xx November 2020 a principle ingredient of various curries, and chutneys, it is also used for vegetables, spices, medicinal, condiments, sauces and pickles with great nutritional value. India has become world's largest producer and exporter of chilli. India and China are the largest exporter of chilli in the world with 25 per cent and 24 per cent share of total global exports, respectively. India is the world's biggest producer and the consumer of red spice, exported 44.90 Thousand MT. chilli, which worth of 22,074.05 lakhs during the year 2017-18. The demand for Indian chilli in international market was from Malaysia, Bangladesh, Sri Lanka, UK and USA. It has been growing on an average between 20 to 25 per cent because of its quality and price competitiveness. The secondary data of chilli export were collected for the period of 1996-97 to 2018-19. For the purpose of comparison, the period was divided into period-I and period-II. To estimate the trade direction, data were analyzed by using first order Markov chain. In the present study, Minimum Absolute Deviations (MAD) estimation procedure was employed to estimate the transitional probability. Result conclude that, Malaysia and Sri Lanka found the most stable market, followed by Vietnam and USA and UAE found most unstable country in importers of Indian chilli.

\section{Introduction}

Chilli (Capsicum annuum L.) is an important vegetable cum spice crop valued for its aroma, taste, flavor and pungency grown in all parts of world. It belongs to the family solanaceae with the chromosome number $2 n=24$ and centre of origin of hot chilli is Mexico. Chilli is cultivated from 3500 BC and it is brought to Asia by Portuguese navigators during the $16^{\text {th }}$ century. Chilli is one of the most valuable spice crop than other spices. Chilli is cultivated largely for its fruit all over the India. It is used in India as a principle ingredient of various curries, and chutneys, it is also used for vegetables, spices, medicinal, condiments, sauces and pickles with great nutritional value and medicinal properties. Rather as a medicine, it is used as a counter irritant in Lumbago, Neuralgia and 
Rheumatic disorders. Capsicum has a tonic and carminative action. Taken devilishly it may cause gastro-enteritis. The enzyme isolated from chilli is used in the treatment of different types of cancers. Oleoresin capsicum is used in pain balms and vaporubs. Chilli has traditional remedy for, asthma, arthritis, blood clots, cluster, pains, headache and burns.

The India's area under chilli cultivation is 316.47 thousand hectare and total chilli production is 3633.99 thousand MT. India, the world's biggest producer and the consumer of red spice, exported 44.90 Thousand MT. chilli, which worth of 22,074.05 lakhs during the year 2017-18). India and china are the largest exporter of chilli in the world with 25 per cent and 24 per cent share of total global exports, respectively. The demands for Indian chilli in the market of Malaysia, Bangladesh, Sri Lanka, UK and USA have been growing on an average between 20 to 25 per cent because of its quality and price competitiveness. India has become world's largest producer and exporter of chilli, exporting to USA, UK, Saudi Arabia, Bangladesh, Pakistan, Sri Lanka, UAE, Singapore, Malaysia, Indonesia, Canada, Vietnam, Germany and many countries across the world.

The main objectives of this study includes to study the direction of trade and changing export pattern of chilli.

\section{Materials and Methods}

The Direction of trade was studied for the country as a whole, were time series data collected from the period 1996-97 to 2017-18 i.e. 22 years data. For the purpose of comparison, the period of study was divided into two sub periods, period-I (from 1996-97 to 2006-07) and period-II (2007-08 to 201718). The data on export quantity and value were collected from website of Directorate General of Commercial Intelligence and
Statistics (DGCIS) i.e. https://commerceapp.gov.in/ and The Agricultural and Processed Food Products Export Development Authority (APEDA). The export data of chilli was collected according to chilli HS code 0904. From the list of chilli importers, top 11 countries, which majored as a regular importers were identified and remaining countries were grouped as other countries. The top 11 countries were USA, Sri Lanka, Malaysia, UAE, UK, Indonesia, Canada, Bangladesh, Pakistan, Thailand and Vietnam. The trade direction of export was analyzed by using first order Markov chain to exam the gains and losses and Minimum Absolute Deviations (MAD) employed to estimate the transitional probability i.e. changing direction of Indian chillii trade.

\section{Markov chain analysis}

The trade directions of export were analyzed using the first order Markov chain approach. Central to Markov chain analysis is the estimation of the transitional probability matrix $\mathrm{P}_{\mathrm{ij}}$. The elements $\mathrm{P}_{\mathrm{ij}}$ of the matrix $\mathrm{P}$ indicates the probability that export will switch from $i^{\text {th }}$ country to $j^{\text {th }}$ country with the passage of time (Dent, 1967; Lee et al., 1970; Gillet, 1976). The diagonal elements of the matrix measure the probability that the export share of a country will be retained. Hence, an examination of the diagonal elements indicates the preference of an importing country to a particular country's exports. In the context of the current application, structural changes were treated as a random process with selected importing countries. The average exports to a particular country was considered to be a random variable which depends only on the past exports to that country, which can be denoted algebraically as

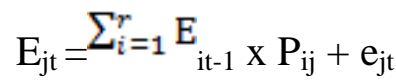

Where, $E_{j t}=$ Exports from India to $j^{\text {th }}$ country during the year $t$. 
$E_{i t-1}=$ Exports from India to $i^{\text {th }}$ country during the period $\mathrm{t}-1$.

$P_{i j}=$ Probability that the exports will shift from $i^{\text {th }}$ country to $j^{\text {th }}$ country.

$E_{j t}=$ The error term which is statistically independent of $\mathrm{E}_{\mathrm{it}-1}$.

$\mathrm{t}=$ Number of years considered for the analysis

$r=$ Number of importing countries

The transitional probabilities $\mathrm{P}_{\mathrm{ij}}$ which can be arranged in a (c x r) matrix have the following properties.

$\mathrm{O} \leq \mathrm{P}_{\mathrm{ij}} \leq 1$

$\sum_{j=1}^{r} \mathrm{P}_{\mathrm{ij}}=1$ for all $\mathrm{i}$

Thus, the expected export shares of each country during period " $t$ " were obtained by multiplying the export to these countries in the previous period $(\mathrm{t}-1)$ with the transitional probability matrix.

\section{Transitional probability (Estimation of the $\mathbf{P}_{\mathrm{ij}}$ )}

matrix

In the present study, Minimum Absolute Deviations (MAD) estimation procedure was employed to estimate the transitional probability, which minimizes the sum of absolute deviations (Fisher, 1961; Wagner, 1959). The conventional linear programming technique was used, as this satisfies the properties of transitional probabilities of nonnegativity restrictions and row sum constraints in estimation.

The linear programming formulation is stated as

Min $\mathrm{OP}^{*}+\mathrm{Ie}$

Subject to,

$\mathrm{XP}^{*}+\mathrm{V}=\mathrm{Y}$

$\mathrm{GP}^{*}=1$

$\mathrm{P}^{*} \mathrm{e} \geq 0$

Where,

$0=$ vector of zeroes.
$\mathrm{P}^{*}=$ vector in which probability $\mathrm{P}_{\mathrm{ij}}$ are arranged.

$\mathrm{I}=$ appropriate dimensioned column vector of units.

$\mathrm{e}=$ vector of absolute error $(|\mathrm{U}|)$.

$\mathrm{Y}=$ vector of export to each country.

$\mathrm{X}=$ block diagonal matrix of lagged values of $\mathrm{Y}$

$\mathrm{V}=$ vector of errors

$\mathrm{G}=$ grouping matrix to add the row elements of $\mathrm{P}$ as arranged in $\mathrm{P}^{*}$ to unity.

After calculating the transitional probability matrix, the expected shares of export were calculated by

$\mathrm{Y}_{\mathrm{jt}}=\sum_{j=1}^{r} y_{\mathrm{it}-1} \times \mathrm{P}_{\mathrm{ij}}(\mathrm{j}=1,2,3 \ldots \mathrm{r})$

Where,

$Y_{j t}=$ Predicted proportions of $j^{\text {th }}$ country's share at time ' $\mathrm{t}$ '.

$\mathrm{Y}_{\mathrm{t}-1}=$ Observed proportion of $i^{\mathrm{th}}$ country share at time 't-1'.

$\mathrm{P}_{\mathrm{ij}}=$ Estimated transitional probability matrix.

\section{Results and Discussion}

\section{Export Trade Pattern during the Period-I (1996-97 to 2006-07)}

From Table 1, Malaysia is the most stable markets of Indian chilli as reflected by the high probability retention of 0.8135 , i.e., the probability that Malaysia retained its export share from one period to another was about 81 per cent during period-I (1996-97 to 200607). Similar interpretation could be made for other countries with probability retention of 0.6099 , Sri Lanka with probability retention of 0.5923 and USA with the probability retention of 0.5371 , Pakistan with probability retention of 0.3939 and Bangladesh with probability retention of 0.1617 , UAE with probability retention of 0.0431 . On the contrary, Indonesia, Thailand and Vietnam were having the probability retention of zero 
showing that they are the unstable importers of Indian chilli in the Period-I over the previous period.

The Malaysia has lost to the quantity of 13.45 per cent to Indonesia, 0.56 per cent to Thailand, 4.63 per cent to other countries, whereas they gained 39.18 per cent from Bangladesh and 12.85 per cent from Pakistan. Therefore, Malaysia retained their original share of 81.35 per cent and lost 18.64 per cent to Indonesia, Thailand and other countries.

Other countries sustained its original share of 60.99 per cent during Period-I over its previous period. However, it gained 75.56 per cent from Thailand, 30.99 per cent from USA, 4.63 per cent from Malaysia and 0.85 per cent from Pakistan, while it lost 32.65 per cent of chilli imports share to USA, 4.22 per cent to UAE and 2.12 per cent to Pakistan.

Sri Lanka retained its original share 59.23 per cent, while it lost 35.43 per cent to Bangladesh and 5.34 per cent to Indonesia however, it gained 93.64 per cent from Indonesia, 44.63 per cent to Bangladesh, 32.29 per cent to Pakistan and 2.87 per cent to USA.

USA retained its original share of 53.71 per cent while it lost 30.99 per cent to other countries, 7.97 per cent to UAE, 4.09 per cent to Bangladesh, 2.87 per cent to Sri Lanka and 0.33 per cent to Indonesia However, it gained 57.94 per cent from China, 32.65 per cent from other countries, 24.43 per cent from Thailand and 6.15 per cent from Pakistan.

Pakistan retained its original share of 39.39 per cent and it gained 2.12 per cent from other countries, 100 per cent from Vietnam, whereas it lost 32.29 per cent to Sri Lanka, 12.85 per cent to Malaysia, 4.52 per cent to Bangladesh, 4.28 per cent to Indonesia, 6.15 per cent to USA and 0.85 per cent to other countries.
Bangladesh retained its original share of 16.17 per cent and it gained 35.43 per cent from Sri Lanka, 33.40 per cent from UAE, 4.52 per cent from Pakistan and 4.09 per cent from USA. Whereas it lost 44.63 per cent to Sri Lanka and 39.18 per cent to Malaysia.

UAE retained its original share of 4.31 per cent and it gained 7.97 per cent from USA and 4.22 per cent from other countries, whereas it lost 57.94 per cent to USA, 33.40 per cent to Bangladesh and 4.34 per cent to Indonesia.

Indonesia could not retain its original share. It has gained 13.45 per cent from Malaysia, 5.34 per cent from Sri Lanka, 4.28 per cent from Pakistan, 4.34 per cent from UAE and 0.33 per cent from USA. Whereas it lost 93.64 per cent to Sri Lanka and 6.36 per cent to Thailand.

Thailand could not retain its original share, it lost 75.56 per cent to other countries and 24.43 per cent to USA and however it gained 6.36 per cent from Indonesia, 0.56 per cent from Malaysia and 0.02 per cent from USA.

Vietnam could not retain its original share, it could not gained from any country. Whereas, it lost 100 per cent to Pakistan.

\section{Export trade pattern during period-II (2007-08 to 2017-18)}

The table 2 showed that, Vietnam was the most stable market for Indian chilli as reflected by the high retention probability of 0.7443 and Malaysia, Sri Lanka, Thailand, other countries, USA and Indonesia were stable markets of the chilli with probabilities of retention coefficients of $0.4187,0.4060$, 0.3966, 0.2388, 0.1130 and 0.0811 respectively. While Bangladesh, Pakistan, UAE showed a zero probability retention indicating that they were unstable importers of Indian chilli during the Period-II. 
Vietnam could retain 74.43 per cent of its share and it lost 12.97 per cent to Indonesia, 12.10 per cent to Thailand and 0.48 per cent to Sri Lanka, however it gained 54.02 per cent from Thailand.

Malaysia retained its original share of 41.87 per cent and it gained 24.46 per cent from U S $A$ and 12.30 per cent from other countries, while it lost 36.45 per cent to USA, 14.62 per cent to Pakistan and 7.04 per cent to other countries

Sri Lanka retained its original share of 40.60 per cent. It has gained 31.70 per cent from UAE, 20.84 per cent from other countries, 17.61 per cent from USA, 2.35 per cent from Bangladesh and 0.48 per cent from Vietnam while it lost 30.98 per cent to Bangladesh, 10.36 per cent to other countries, 7.11 per cent to Indonesia, 6.58 per cent to UAE and 4.55 per cent to U S A.

Thailand retained its original share of 39.66 and it gained 27.33 per cent from other countries, 12.10 per cent from Vietnam and 9.66 per cent from Bangladesh, while it lost 54.04 per cent to Vietnam, 4.02 per cent other countries and 2.28 per cent to Bangladesh.

Other countries retained its original share of 23.88 per cent and it lost 27.33 per cent to Thailand, 20.84 per cent to Sri Lanka, 14.97 per cent to Bangladesh, 12.30 per cent to Malaysia and 0.65 per cent to Indonesia, however it gained 53.80 per cent from Indonesia, 43.39 per cent from Bangladesh and 41.26 per cent from USA, 37.77 per cent from Pakistan, 10.36 per cent from Sri Lanka, 7.04 per cent from Malaysia, 4.02 per cent from Thailand. USA retained its original share of 11.30 per cent and it gained 53.77 per cent from Pakistan, 36.45 per cent from Malaysia, 35.26 per cent from Bangladesh, 16.02 per cent from Indonesia and 4.55 per cent from Sri Lanka, while it lost 41.26 per cent to other countries, 24.46 per cent to
Malaysia, 17.61 per cent to Sri Lanka, 2.79 per cent to Indonesia, 2.57 per cent to UAE.

Indonesia retained its original share of 8.11 per cent and it lost 53.80 per cent to other countries, 22.05 per cent to UAE and 16.06 per cent to USA, however it gained 68.29 per cent from UAE, 12.97 per cent from Vietnam, 7.11 per cent from Sri Lanka, 2.79 per cent from USA, 0.65 per cent from other countries.

Bangladesh could not retain its original share and it gained 30.98 per cent from Sri Lanka, 14.97 per cent from other countries and 2.28 per cent from Thailand, while it lost 43.39 per cent to other countries, 35.26 per cent to USA, 9.66 per cent to Thailand, 8.02 per cent to Pakistan, 2.35 per cent to Sri Lanka, 1.32 per cent to UAE. Pakistan could not retain its original share and it has gained 14.62 per cent from Malaysia and 8.02 per cent from Bangladesh, while it lost 53.77 per cent to USA, 37.77 per cent to other countries, 8.45 per cent to UAE.

UAE could not retain its original share and it gained 22.05 per cent from Indonesia, 8.45 per cent from Pakistan, 6.58 per cent from Sri Lanka, 2.57 per cent from USA and 1.31 per cent to Bangladesh, while it lost 68.29 per cent to Indonesia and 31.70 per cent to Sri Lanka.

Thus, it was clear that in study period-I Indonesia, Thailand and Vietnam were the most unstable importers of the chillies as they could not retained their original shares. Bangladesh, Malaysia, Sri lanka and USA could be termed as stable importers. During the period-II Bangladesh, Pakistan and UAE were the most unstable importers and Malaysia, Sri lanka, Thailand and Vietnam could be termed as stable importers and they can be potential destinations for the Indian chillies in future. These result similar to Bhavani Devi et al., (2016) for study period 2004-05 to 2010-2011. 
Table.1 Trade direction of chilli export from India to major destinations during first period of the study

\begin{tabular}{|c|c|c|c|c|c|c|c|c|c|c|}
\hline Countries & Bangladesh & Indonesia & Malaysia & Pakistan & Sri Lanka & Thailand & U S A & UAE & Vietnam & Others \\
\hline Bangladesh & $\mathbf{0 . 1 6 1 7}$ & 0.0000 & 0.3918 & 0.0000 & 0.4463 & 0.0000 & 0.0000 & 0.0000 & 0.0000 & 0.0000 \\
\hline Indonesia & 0.0000 & $\mathbf{0 . 0 0 0 0}$ & 0.0000 & 0.0000 & 0.9364 & 0.0636 & 0.0000 & 0.0000 & 0.0000 & 0.0000 \\
\hline Malaysia & 0.0000 & 0.1345 & $\mathbf{0 . 8 1 3 5}$ & 0.0000 & 0.0000 & 0.0056 & 0.0000 & 0.0000 & 0.0000 & 0.0463 \\
\hline Pakistan & 0.0452 & 0.0428 & 0.1285 & $\mathbf{0 . 3 9 3 9}$ & 0.3229 & 0.0000 & 0.0615 & 0.0000 & 0.0000 & 0.0085 \\
\hline Sri Lanka & 0.3543 & 0.0534 & 0.0000 & 0.0000 & $\mathbf{0 . 5 9 2 3}$ & 0.0000 & 0.0000 & 0.0000 & 0.0000 & 0.0000 \\
\hline Thailand & 0.0000 & 0.0000 & 0.0000 & 0.0000 & 0.0000 & $\mathbf{0 . 0 0 0 0}$ & 0.2443 & 0.0000 & 0.0000 & 0.7556 \\
\hline U S A & 0.0409 & 0.0033 & 0.0000 & 0.0000 & 0.0287 & 0.0002 & $\mathbf{0 . 5 3 7 1}$ & 0.0797 & 0.0000 & 0.3099 \\
\hline UAE & 0.3340 & 0.0434 & 0.0000 & 0.0000 & 0.0000 & 0.0000 & 0.5794 & $\mathbf{0 . 0 4 3 1}$ & 0.0000 & 0.0000 \\
\hline Vietnam & 0.0000 & 0.0000 & 0.0000 & 1.0000 & 0.0000 & 0.0000 & 0.0000 & 0.0000 & $\mathbf{0 . 0 0 0 0}$ & 0.0000 \\
\hline Others & 0.0000 & 0.0000 & 0.0000 & 0.0212 & 0.0000 & 0.0000 & 0.3265 & 0.0422 & 0.0000 & $\mathbf{0 . 6 0 9 9}$ \\
\hline
\end{tabular}


Table.2 Trade direction of chilli export from India to major destinations during second period of the study

\begin{tabular}{|c|c|c|c|c|c|c|c|c|c|c|}
\hline Countries & Bangladesh & Indonesia & Malaysia & Pakistan & Sri & Thailand & U S A & UAE & Vietnam & Others \\
\hline Bangladesh & $\mathbf{0 . 0 0 0 0}$ & 0.0000 & 0.0000 & 0.0802 & 0.0235 & 0.0966 & 0.3526 & 0.0131 & 0.0000 & 0.4339 \\
\hline Indonesia & 0.0000 & $\mathbf{0 . 0 8 1 1}$ & 0.0000 & 0.0000 & 0.0000 & 0.0000 & 0.1602 & 0.2205 & 0.0000 & 0.5380 \\
\hline Malaysia & 0.0000 & 0.0000 & $\mathbf{0 . 4 1 8 7}$ & 0.1462 & 0.0000 & 0.0000 & 0.3645 & 0.0000 & 0.0000 & 0.0704 \\
\hline Pakistan & 0.0000 & 0.0000 & 0.0000 & $\mathbf{0 . 0 0 0 0}$ & 0.0000 & 0.0000 & 0.5377 & 0.0845 & 0.0000 & 0.3777 \\
\hline Sri Lanka & 0.3098 & 0.0711 & 0.0000 & 0.0000 & $\mathbf{0 . 4 0 6 0}$ & 0.0000 & 0.0455 & 0.0658 & 0.0000 & 0.1036 \\
\hline Thailand & 0.0228 & 0.0000 & 0.0000 & 0.0000 & 0.0000 & $\mathbf{0 . 3 9 6 6}$ & 0.0000 & 0.0000 & 0.5402 & 0.0402 \\
\hline U S A & 0.0000 & 0.0279 & 0.2446 & 0.0000 & 0.1761 & 0.0000 & $\mathbf{0 . 1 1 3 0}$ & 0.0257 & 0.0000 & 0.4126 \\
\hline UAE & 0.0000 & 0.6829 & 0.0000 & 0.0000 & 0.3170 & 0.0000 & 0.0000 & $\mathbf{0 . 0 0 0 0}$ & 0.0000 & 0.0000 \\
\hline Vietnam & 0.0000 & 0.1297 & 0.0000 & 0.0000 & 0.0048 & 0.1210 & 0.0000 & 0.0000 & $\mathbf{0 . 7 4 4 3}$ & 0.0000 \\
\hline Others & 0.1497 & 0.0065 & 0.1230 & 0.0000 & 0.2084 & 0.2733 & 0.0000 & 0.0000 & 0.0000 & $\mathbf{0 . 2 3 8 8}$ \\
\hline
\end{tabular}


Direction of trade concludes that, Malaysia and Sri lanka be the most stable market, followed by Vietnam and USA. The UAE are the most unstable country in importers of Indian chilli.

Conclusion of the study is as follows:

Indonesia, Thailand and Vietnam found most unstable importers of the chilli in period-I and Bangladesh, Malaysia, Sri Lanka and USA found most stable importers.

Bangladesh, Pakistan and UAE are found most unstable importers in period-II and Malaysia, Sri Lanka, Thailand and Vietnam found most stable importers.

In overall trade, direction Malaysia and Sri Lanka found the most stable market, followed by Vietnam and USA and UAE found most unstable country in importers of Indian Chilli.

\section{Policy Implications}

Government should help to entrepreneurs by initiate incentives $\&$ policies, helping by subsidies, proper documentation and procedure for chilli export, proper export duties on exportable commodities and encouragement to new start ups.

There is need for better infrastructure, transportations and storage facilities to chilli growers for export.

Government should make easier documentation for export policies.

\section{References}

Angles, S., Sundar, A. and Chinnadurai, M. (2011). Impact of Globalization on Production and Export of Turmeric in India - An Economic Analysis, Agricultural Economics Research Review, 24 (1): 301-308.

Aravinda kumar, M. K., Gaddi, G. M.,
Manjunath, L., Ashwini, B. C., Bavya, A. P. and Prakash, M. (2015). Export performance of Indian cashew, International Research Journal of Agricultural Economics and Statistics, 6 (2): 349-355.

Ashoka, N., Kuldeep, C., Ramachandra, V. A., and Yeledhalli, R. A. (2013). A study on growth, instability and direction of chilli trade in India, Journal of Spices and Aromatic Crops, 22 (1): 76-80.

Bhavani Devi, Srikalab, M., Ananda, T. and Subramanyam, V. (2016). Direction of Trade and Export Competitiveness of Chillies in India, Agricultural Economics Research Review, 29 (2): 267-272.

Chaitra, G. B., and Sonnad, J. S. (2019). Export performance of chilli and cumin from India: An empirical analysis, Journal of Pharmacognosy and Phytochemistry, 8 (2): 2014-2020.

Joshi, D. and Singh, H. P. (2014). An Empirical Analysis of Growth and Instability in Major Spices In India, International Journal of Agriculture Sciences, 7 (2): 440-444.

Joshi, D., Singh, H. P., and Gurung, B. (2015). Stability Analysis of Indian Spices Export - A Markov Chain Approach, Economic Affairs, 60 (2): 257-262.

Kusuma, D. K. and Kumara, B. R. (2014). Changing direction of Indian onion exports, International Journal of Agricultural Sciences, 10 (1): 198-201

Mendhe, N. P. and Degaonkar, A. M. (2010). Export of performance of Indian chilli, International Journal of Commerce and Business Management, 3(2): 252-257.

Rajur, B. C. and Patil, B. L. (2013). Export performance of chilli - An analysis, Karnataka Journals of Agriculture Science, 26(2): 233-237. 


\section{How to cite this article:}

Gade, P. A., S. S. More, R. D. Shelke and Nalegaonkar, A. R. 2020. Direction of Trade and Changing Export Pattern of Chilli. Int.J.Curr.Microbiol.App.Sci. 9(11): 2638-2646. doi: https://doi.org/10.20546/ijcmas.2020.911.320 